\title{
Quranic app practices among multilingual Muslim youth in Denmark
}

\author{
Line Møller Daugaard, VIA University College
}

\begin{abstract}
This article sheds light on a set of religious literacy practices which have so far received very little scientific attention, namely 'quranic app practices'. Quranic app practices are conceptualized as ways of engaging with the Quran through religious apps on smartphones or tablets. The article is based primarily on an explorative group interview with four young people from a Year 8 class in a multilingual lower secondary school in Denmark. The youth have Somali and Afghan background, consider themselves practicing Muslims and can be described as 'religious heritage learners of Arabic' (Temples 2013). The article explores the quranic app practices of the young people as reported in the interview and shows how the young people use the quranic apps to engage with the sacred text of the Quran in different ways, with different objectives and drawing on different languages. Building on Rosowsky's $(2008,2010,2012,2013,2015)$ research on faith literacies, the analysis reveals that the young people have radically different understandings of that it entails to 'read the Quran' and that their quranic app practices vary greatly, but also that their choice of app is consistent with their stated objectives, priorities, preferences and practices. The different quranic app practices thus all appear meaningful, consistent and legitimate. Based on the analysis, the article calls for further investigation of young people's quranic app practices.
\end{abstract}

Keywords: classical Arabic, faith literacies, quranic apps, multilingual youth, language and identity

\section{Introduction}

To many children and young people with a Muslim background in the Scandinavian countries today, language and literacy practices originating in quranic schools or in other kinds of engagement with the Quran constitute an integrated - but to outsiders often largely unnoticed - part of everyday life and of the children and young people's linguistic repertoires. Some go to more or less formalized quranic schools; others receive Arabic or quranic lessons at home, either face-to-face or through internet-based communication platforms; others again regularly interact with the Quran through religious apps on their smartphones or tablets. This article focuses on the latter, namely quranic app practices, among multilingual Muslim youth in Denmark.

Corresponding author's email: lida@via.dk

ISSN: 1457-9863

Publisher: Centre for Applied Language Studies

University of Jyväskylä

(C) 2019: The authors

http:/ /apples.jyu.fi

http://dx.doi.org/10.17011/apples/urn.201912185424 
The primary empirical point of departure is an exploratory group interview with four young people to whom the Quran is potentially at hand 24/7 through quranic apps on their smartphones or tablets. The youth are 14-15 years old and go to the same Year 8 class in a Danish lower secondary school. They have different backgrounds, speak different languages at home - Somali, Dari and Pashto - and have various levels of Arabic literacy competence, but they all consider themselves practicing Muslims, and they regularly use quranic apps. The article explores the quranic app practices as reported by the young people and illustrate how the quranic apps take up different functions in the young people's everyday lives. The article describes the young people's criteria for selection of apps, their understandings of what constitutes a good quranic app, and their preferences and strategies for use of the apps and for engagement with the quranic text and other content.

The international research on quranic app practices is very sparse, and the theme has so far received very little scientific attention and therefore often go unnoticed in the public sphere as well as in the educational system. The article thus sheds light on a set of literacy practices which remain sketchily researched, but which have great importance for our understanding of everyday lives and linguistic repertoires of multilingual Muslim youth in diasporic settings today.

\section{Theoretical framework}

\subsection{From maktab literacy practices to digital religion}

Religious literacy practices - also known as faith literacies (Gregory, Choudhury, Ilankuberan, Kwapong, \& Woodham, 2013; Rosowsky, 2015) - are neither a new nor an unexplored phenomenon. The theorization of literacy as social practice as well as the concept of 'literacy practice' itself originally sprang from Street's seminal observations of ways of using literacy in the village of Cheshmeh in Iran in the 1970s (Street, 1984, 1995, 2001; see also Street, Pishghadan, \& Zeinali, 2015). Based on his fieldwork in Cheshmeh, Street described three sets of literacy practices: schooled literacy, maktab literacy and commercial literacy. While schooled literacy was tied to the villagers' encounter with the national educational system, maktab literacy developed around the maktabs which were Islamic religious schools where mullahs introduced the villagers to the Quran with a strong focus on recitation and rote learning. The third literacy practice, commercial literacy, was tied to the fruit commerce vital to the village and productively built on maktab literacy rather than on schooled literacy.

Street's description of literacy practices in Cheshmeh in the 1970s laid the foundation for the so-called social definition of literacy (Street et al., 2015, p. 16) and has since then provided a strong source of inspiration for studies of literacy practices across the world - in religious settings as well as a in range of other contexts. In his state-of-the-art introduction to faith literacies, Rosowsky (2015) provides a description of a complex of textual activities which he labels "typical Qur'anic practices" (p. 171). He describes how the Quran as a book is used extensively in both the liturgy in the mosque and in private or group devotion. He stresses the importance of the activities of reading and reading aloud of the Quran, e.g. during Ramadan or to accompany birth and death, and he points to the material (omni)presence of the Quran in everyday life: On shelves and in 
bookcases, through decorative calligraphy on walls, on credit-card size verses in wallets or on jewellery (see also Rosowsky, 2008, pp. 8-9). However, digital quranic literacy practices seem to be largely missing from Rosowsky's elaborate picture of quranic literacy practices in everyday life.

In a recent Norwegian study, however, Aarset (2015) describes an interesting example of a digital quranic literacy practice, namely extensive use of online quranic courses via Skype in the Norwegian-Pakistani community in Oslo. Aarset's study points to the rapid transformation of religious literacy practices in an increasingly digitized global communicative landscape. Both individuals and communities from various religious backgrounds increasingly use new media, including mobile media and apps, for religious purposes (cf. Campbell, 2013; Campbell, Altenhofen, Bellar, Cho, 2014). The emerging research field of digital religion explores the intersection between religious experience and new technologies - so-called "emerging techno-spiritual practices" (Campbell et al., 2014, p. 156).

A subset of studies explore how religion is practiced through mobile media and apps and how the apps both enable and constrain religious rituals and meaningmaking (i.e. Bellar, 2012; Torma \& Teusner, 2011; Wagner, 2013). None of these studies, however, focus specifically on quranic apps. The same goes for Vollmer (2018) who conducts an in-depth linguistic ethnography on the digital literacy practices of Syrian refugees, investigating how three male newcomers to England use technologies and online resources such as facebook groups, apps and social media platforms to support processes of settlement and linguistic integration (Vollmer, 2017, 2018). While Vollmer provides thought-provoking analyses of app use for obtaining a driver's licence and offering plumbing services, he does not investigate any use of apps for religious purposes. In the following, I focus specifically on first religious and then quranic apps as a subset of digital religious literacy practices.

\subsection{Digital religion - religious and quranic apps}

Campbell and colleagues present a critical framework for studying religiousoriented apps based on a review of more than 400 religious apps (Campbell et al 2014). The total sample of 451 apps cover the five major world religions Buddhism, Christianity, Hinduism, Islam and Judaism - and contains 107 Muslim apps. The apps are categorized into two parent classifications; apps oriented around religious practice and apps embedded with religious content. The apps oriented around religious practice are designed specifically for religious purposes and serve an inherently religious function by facilitating concrete religious activities such as engagement with sacred text, prayer or ritual. Apps embedded with religious content provide access to religious information or material, but embed religious content into secular practices - for instance quizzes or games rather than facilitate established religious practice. Table 1 below provides an overview of parent categories, subcategories, number of apps and a telling example of a religious app in each subcategory: 
Table 1. Typology of religious apps.

\begin{tabular}{|c|c|c|c|}
\hline \multicolumn{4}{|c|}{ Apps oriented around religious practice } \\
\hline Sacred Textual Engagement & $n=71$ & The Holy Quran & (Muslim) \\
\hline Prayer & $\mathrm{n}=65$ & iPray & (Jewish) \\
\hline Focus/Meditation & $\mathrm{n}=41$ & $\begin{array}{l}\text { Buddha Box HD } \\
\text { (Buddhist) }\end{array}$ & \\
\hline Devotional Worship & $n=32$ & $\begin{array}{l}\text { Girlfriends in God Devotional } \\
\text { (Christian) }\end{array}$ & \\
\hline Ritual & $\mathrm{n}=31$ & Lulav Wizard & (Jewish) \\
\hline \multicolumn{4}{|c|}{ Apps embedded with religious content } \\
\hline Religious Utilities & $\mathrm{n}=106$ & Qibla Compass & (Muslim) \\
\hline Religious Wisdom and Leaders & $\mathrm{n}=60$ & An-Nawai's Forty Hadiths & (Muslim) \\
\hline Religious Media Outlets & $\mathrm{n}=37$ & Hope for Today & (Christian) \\
\hline Religious Games & $n=31$ & Islamic Quiz & (Muslim) \\
\hline Religious Apps for Kids & $n=31$ & Quran Stories for Kids & (Muslim) \\
\hline
\end{tabular}

(my recount of Campbell et al., 2014)

The typology provides interesting insight into the range of religious apps available and the varied functions which religious apps are designed to serve and thus underlines the fact that religious apps constitute an integral part of contemporary religious literacy practices - not just for practicing Muslims, but across religious traditions. As for the Muslim apps in the sample, they are - like other religious apps - designed to serve many different functions, but are generally described as "scripturally oriented" (Campbell et al., 2014, p. 162) and hence largely oriented towards engagement with the sacred text of the Quran.

Recent Islamic studies on religious apps explore the consequences of the digitization of the Quran in quranic apps. Khan and Alginahi compare practicing Muslims' understandings of reading the Quran using the traditional printed book version (mushaf) and the digital version available through quranic apps (Khan \& Alginahi, 2013). The respondents to their questionnaire - most of them Saudi Arabian adults - mention convenience, portability and extended possibilities for privacy as key advantages of the digital version available through apps, but also raise important concerns. They worry about the authenticity and correctness of the digital version, and they regret that the feeling of reverence and spirituality arising from engagement with the printed version of the sacred text is lost when using a quranic app.

Exactly the question of proper handling of the digital text format is at the heart of Alwi and colleagues' discussion of "issues of Islamic jurisprudence" (Alwi, Anas, Ibrahim, Dahan, \& Yaacob, 2014, p. 212). They ask whether formal religious regulations concerning the handling of the mushaf are applicable to the use of quranic apps: Should the user of a quranic app carefully wash before reading $(w u d h u)$ and respect the direction of prayer while reading (qibla)? May menstruating woman use the app? Can the device containing the digital version of the Quran be taken to the toilet? The Islamic studies of quranic apps make it clear that quranic app practices involve more than choosing and using an appropriate app; it also inevitably raises abstract and morally laden questions of good or bad and right or wrong.

The review of the research points to young people's use of quranic apps in everyday life as an under-researched area. While ethnographic and literacyoriented studies seem not to include either digital quranic practices in general or quranic app usage in particular, the Islamic studies tend to privilege normative 
religious issues related to quranic apps rather than app use. Furthermore, the Islamic studies primarily focus on adults in predominantly Muslim communities in Saudi Arabia or Malaysia and not young Muslims in diasporic settings which is the case in this article. In the following sections, I provide a closer description of this particular group of multilingual Muslim youth in diasporic settings.

\subsection{Religious heritage learners of Arabic}

My interest in quranic app practices is neither directed at the religious nor the technological aspects of quranic app practices per se; I am interested in quranic app practices as language and literacy practices that form an integral part of practicing Muslim youth's linguistic repertoires.

In this respect, Temples' (2013) work provides important inspiration. Temples sheds light on the intricate patterns of investment in and identification with Arabic language and literacy in a diverse community around a U.S. public charter school offering daily lessons in Arabic to all children, regardless of linguistic and religious background. Many of the families opting for the school have a Muslim background or affiliations to Islam, but the school also serves a number of families who are neither Arabic speakers nor Muslims (Temples, 2013, p. 63). In order to capture this complexity, Temples calls for a deconstruction of the notions of 'heritage learner' and 'heritage language' in relation to Arabic (Temples, 2013, p. 112). Temples thus replaces the traditional dichotomy between 'heritage learner' and 'non-heritage learner' of Arabic with a tripartite typology distinguishing between three sets of relations to Arabic language and literacy:

Table 2. Typology of relations to Arabic language and literacy.

\begin{tabular}{ll}
\hline Arab Heritage Learners & Children from Arabic-speaking families \\
\hline $\begin{array}{l}\text { Religious Heritage } \\
\text { Learners }\end{array}$ & $\begin{array}{l}\text { Children who do not use Arabic for family communication, but } \\
\text { encounter Arabic in religious practice }\end{array}$ \\
\hline $\begin{array}{l}\text { Foreign Language } \\
\text { Learners }\end{array}$ & $\begin{array}{l}\text { Children who use English or another language other than Arabic } \\
\text { for family communication and do not use Arabic for religious } \\
\text { purposes }\end{array}$ \\
\hline
\end{tabular}

(my recount of Temples, 2013, p. 108)

With the interjection of a third category - the religious heritage learners of Arabic between the common categories of 'heritage' and 'non-heritage learners', Temples creates a legitimate space for children and youth who do not use Arabic for family communication, but encounter Arabic in religious practice, exactly as it is the case for the four young people featuring in the analysis of quranic app practices in this article. Being of Somali or Afghan descent, they fall short of immediate categorization as 'mother tongue speakers' or 'heritage speakers' of Arabic since they do not primarily speak Arabic at home. On the other hand, they have - through religious practice - acquired an important amount of experience with, knowledge of and investment in Arabic language and literacy that clearly delineate them from children readily categorizable as 'foreign language learners' of Arabic.

The four young people - who I in the following will refer to by the pseudonyms Roshina, Zohal, Homa and Guled - can all be considered religious heritage learners of Arabic. In the following, I describe the specific variety of Arabic which they and other religious heritage learners of Arabic engage with through religious practice. 


\subsection{Arabic as religious classical}

As religious heritage learners of Arabic, Roshina, Zohal, Homa and Guled engage with a highly specialized register of Arabic. As pointed out by Temples, "Arabic is not a monolithic target, but represents a multiplicity of varieties and skills that can be, and are, viewed, valued and negotiated separately" (Temples, 2013, p. 202). The glossonym 'Arabic' is a cover term for what Holes describes as "kaleidoscopic variation" (Holes, 2004, p. 40) involving three main - and co-existing - registers: Classical Arabic, Modern Standard Arabic and a range of colloquial Arabic varieties also referred to as dialects or national vernaculars (cf. Haeri, 2000).

The register of importance here is Classical Arabic, the religious language of the Quran and of Islam. While everyday informal interaction is the natural site of social reproduction of colloquial Arabic and education and media the site of reproduction of Modern Standard Arabic, Classical Arabic is primarily reproduced through religious practice. As the liturgical language of Islam, Classical Arabic functions as the primary language of worship, prayer and study for Muslims across the world (Temples 2013, p. 29):

Practicing Muslims all over the world read the Qur'an, memorize suras from the Qur'an, and pray in classical Arabic, no matter what language they use in their day to day life. They believe that the Qur'an itself is a miracle, revealed by God to Muhammad in Arabic, and thus Arabic itself is sacred. (Temples 2013, p. 28)

Haeri (2000) describes Islam and Classical Arabic as "mutually constitutive" (p. 79). Whereas the Christian holy book, the Bible, has been translated to more than 500 languages and is read in translation in Christian communities across the world, the Quran is read and recited in Classical Arabic by practising Muslims, regardless of linguistic background. Haeri describes how form and meaning of the Quran are believed to be inseparable: “The language of the Qu'ran, they explained, is after all the word of God and one must read His word and not some translation of it" (Haeri, 2000, p. 75). Classical Arabic thus occupies a distinct and privileged ideological position among practicing Muslims across the world:

Classical Arabic is revered by rich, poor, educated, and illiterate alike as the linguistic jewel in the Islamic cultural patrimony. It is regarded as the inimitable apogee of perfection, unsurpassable in beauty, an ethereal ideal of eloquence, perfect symmetry, and succinctness - however imperfectly, in practice, many Arabs understand it. (Holes, 2004, p. 5)

Religious Islamic practice is thus inextricably tied to Classical Arabic. The sound of Classical Arabic, with its distinct rhythm and cadence, belongs to the earliest conscious linguistic experiences of many children in Muslim families and according to Holes leaves "an indelible impression, reinforced throughout later life in the constant ritual of prayers and attendance at the mosque" (Holes, 2004, p. 5).

In the context of quranic app practices in focus in this article, it is therefore important to note that when Roshina, Zohal, Homa and Guled talk about 'Arabic', they do not refer to any variety of Arabic, but typically to the highly specialized, strictly codified and emotionally laden variety of Classical Arabic. This engagement is elaborately described in Rosowsky's (2008, 2010, 2012, 2013, 2015) extensive sociolinguistic and ethnographic research in faith literacies in the UK. Rosowsky has focused primarily on Muslim faith communities and on quranic 
schools, but has also explored Jewish cheder and Sikh gurdwara faith complementary schools, and his research for instance covers the nature of reading instruction and questions of language choice in the faith complementary schools (Rosowsky, 2013), young Muslim's script choices (Rosowsky, 2010) and the performative nature of religious literacy practices (Rosowsky, 2012). Building on Fishman (1989), Rosowsky conceptualizes the liturgical language which children and young people learn to read, memorise and recite within faith complementary schools as a 'religious classical' (Rosowsky 2012, 2013), and his research highlights the important symbolic meaning of the religious classical for individual and collective identity formation. As we will see in the analysis, the symbolic value of Classical Arabic also features prominently in Roshina, Zohal, Homa and Guled's quranic app practices.

\section{Methodological framework}

\subsection{Signs of language}

The exploration of Roshina, Zohal, Homa and Guled's quranic app practices springs from a many-facetted empirical material produced in the longitudinal research project Signs of Language (2008-2018) investigating literacy teaching in multilingual classrooms. In Signs of Language, five classes across Denmark were followed closely by a research team through primary and lower secondary school with two connected research interests: To explore the nature of linguistic diversity in contemporary Danish schools from a social semiotic perspective and to seek potential for didactic development and change (cf. Laursen et al., 2018b). Data were collected through classroom observations and interviews as well as through researcher-generated activities and interventions planned in collaboration with the literacy teachers in the classes (cf. Laursen \& Mogensen, 2016).

As a member of the Signs of Language research team, I was responsible for one of five classes throughout the project period, and the four young heritage learners of Arabic all went to this class in a public school on the outskirts of a large city in Denmark. I met Roshina, Zohal, Homa and Guled and their class mates and teachers for the first time in August 2008 and since then observed the class on a regular basis until the class finished lower secondary school in June 2018. While the research interest in Signs on Language primarily centered on language and literacy practices pertaining to Danish teaching, I in my concurrent doctoral research project (2010-2015) focused on mother tongue teaching in Arabic, Dari, Pashto and Somali which two thirds of the children in class regularly attended during primary school (cf. Daugaard, 2015).

A combination of empirical material and insights from the two research projects forms the background for the analysis of quranic app practices. The primary data comes from one specific exploratory group interview with Roshina, Zohal, Homa and Guled on their ways of using quranic apps performed as part of Signs of Language when the youth were in Year 8. In the following, I first present Roshina, Zohal, Homa and Guled as young heritage learners of Arabic, drawing on various supplementary background data from Signs of Language, before I provide a detailed description of the exploratory group interview on quranic app practices. 


\subsection{Roshina, Zohal, Homa and Guled: Four young religious learners of Arabic}

Roshina, Zohal, Homa and Guled were all born in Denmark by parents of Afghan or Somali background. The families of the three girls - Roshina, Zohal and Homa - came to Denmark from Afghanistan and Guled's family from Somalia. Roshina and Homa both speak Dari at home, while Zohal comes from a primarily Pashtospeaking family, and Guled speaks Somali at home. In primary school, all four participated in weekly mother tongue teaching in Dari, Pashto and Somali, respectively. The Danish language occupies an important place in the linguistic repertoire of all four young people; Danish is for all of them the language they feel most confident in and which they believe will be important for their future life. They have furthermore received English teaching from Year 1 and German teaching from Year 5.

Across the differences in individual linguistic repertoires, narratives about encounters with Arabic as a religious classical have been a consistent and recurrent feature all the way through primary and lower secondary school - not just in this class, but in all five classes in Signs of Language. In order to portray Roshina, Zohal, Homa and Guled as religious heritage learners of Arabic, I in the following include background data from Sign of Language and - for reasons of space - focus especially on Zohal.

In Year 1, I interviewed Zohal and Guled during a peer teaching activity as part of Signs of Language. In pairs, the 7-8 year old children were invited to take on the role as teacher and teach me and the other child about writing - what and how they decided for themselves (see Laursen, 2013, for further details). Zohal had decided to teach Guled about Pashto writing, and Guled wanted to teach Zohal to write in Somali. But soon the conversation turned to the Arabic script which they were both familiar with from quranic school. Guled went to one quranic school in the neighbourhood along with other Somali boys, while Zohal attended another quranic school close by - along with both Dari and Pashto speaking children, but girls and boys apart. Zohal proudly told me that she had become a 'teacher' in quranic school: Because she was ahead of the other girls in her age group, she had been trusted to read selected suras (chapters of the Quran) in Arabic to younger girls.

Eight years later, in Year 9, Arabic still constitutes an integral part of Zohal's linguistic repertoire. Like the rest of the class, she produced an individual language portrait as part of an intervention in literacy teaching in Signs of Language. A language portrait consists of a generic body silhouette which the language user is invited to colour in order to illustrate the languages and linguistic varieties in his or her linguistic repertoire (cf. Busch, 2018; Daugaard, Jensen, \& Kristensen, 2018; Krumm \& Jenkins, 2001). The language portrait is based on a theoretical understanding of the linguistic repertoire as an embodied and "chronotopically layered disposition" providing insight into "discourses and ideologies that tell us who we are or what we are able to think, feel and desire" (Busch 2018, pp. 4-5). Methodologically, the subjective and creative visualization process invite language users to reflect on language and literacy practices and preferences that may otherwise pass without awareness or be considered peripheral.

In Zohal's class, the language portraits were made on the basis of a digital photo of the young people instead of a generic body silhouette (cf. Prasad 2014) and were accompanied by a written essay (see Laursen et al 2018a for further details on the intervention). 


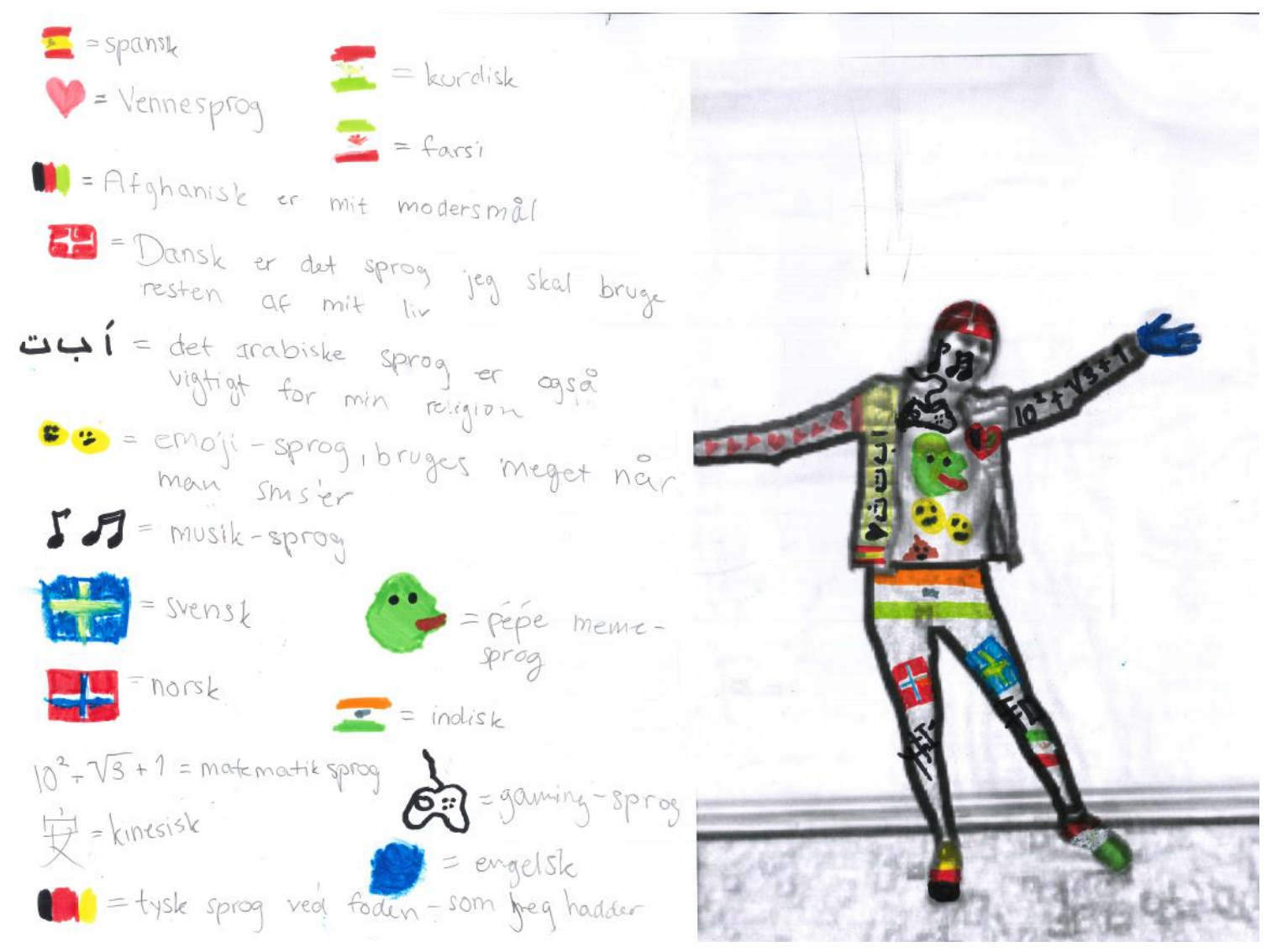

Figure 1. Zohal's language portrait.

Zohal's language portrait contains a colourful collection of languages, literacies and registers. She has placed 'Afghanish' at heart - "this is my mother tongue". Her head is filled with Danish - "the language I will be using the rest of my life". English is (uncommented) by her right hand, German at her left foot - "I hate it". Her language portrait also contains a range of other languages which she has picked up bits and pieces of from friends, relatives, media and travels: Spanish, Kurdish, Norwegian, Swedish, Chinese and Farsi - as well as an unspecified 'friend language' symbolized by pink hearts. School registers such as 'mathematical language' as well as out-of-school registers like 'gaming language' and 'music language' are also present, and her language portrait furthermore contains multimodal registers relating to social media communication, 'emoji language' and 'meme language'. And finally, Zohal's language portrait involves Arabic, symbolized by the iconic first three letters of the Arabic alphabet. In her explanatory note, she writes: "The Arabic language is also important to my religion".

The background data on Zohal shows how Arabic language and literacy has been an integral part of her everyday life all the way through primary and lower secondary school. Her language portrait provides a many-facetted insight into her complex linguistic repertoire towards the end of lower secondary school - a repertoire in which Zohal gives Danish, 'Afghanish' and classical Arabic a central position and on which her digital communicative practices have left their distinctive mark. 
With this insight into the linguistic repertoire of a young religious heritage learner of Arabic as a backdrop, I now turn to the exploratory group interview with Zohal, Roshina, Homa and Guled on their quranic app practices.

\subsection{An exploratory group interview: Affordances and limitations}

The exploratory group interview was one of three interviews conducted by me as a researcher as part of an intervention in Danish literacy teaching in Signs of Language in 2016 when Roshina, Zohal, Homa and Guled were at the beginning of Year 8 (see Daugaard, 2017, for a detailed description of the intervention). The intervention focused on reading comprehension, reading strategies and reader roles, and while the two literacy teachers in class were responsible for the literacy teaching, I as a researcher was responsible for conducting three interviews with smaller groups of pupils. The three interviews evolved around topics identified by the literacy teachers in class as crucial in order to gain a fuller understanding of the literacy practices of the pupils. The interview in focus in this article was designed to shed light on pupils' experiences with reading the Quran through an app; the two other interviews explored reading in English and reading in Danish by means of the reading-assisting app IntoWords.

The exploratory group interview was conducted as a qualitative research interview (Tanggaard \& Brinkmann, 2010) and based on an understanding of the research interview as a social practice (Holstein \& Gubrium, 1995). It is thus acknowledged that interviewing is not a neutral elicitation technique which provides the researcher with unmediated access to the interview participants' life worlds; the research interview is - like other conversations - a situated encounter where interviewer and interviewees produce socially negotiated and contextually and interactionally shaped responses to each other's contributions.

The group interview can be described as a semi-structured interview and aimed at gaining an emic perspective on using quranic apps. For ethical reasons, participation in the group interview on quranic app practices was made voluntary. I knew from previous observations and informal conversations in class that several pupils in class - and indeed more than the four pupils participating in the group interview - had quranic apps on their tablets or smartphones. However, while the literacy practices in focus in the two other interviews - reading in English and using a reading-assisting app for reading Danish, respectively - are literacy practices taking place as an overt and naturalised part of everyday school life, the use of quranic apps typically takes place outside of school and rather belongs to the private sphere and may therefore be perceived as delicate subjects to deal with in the school setting. For ethical reasons, I therefore in this particular interview openly announced the topic of the interview in class and asked if any of the pupils regularly using quranic apps would like to participate in an interview with me. Roshina, Zohal, Homa and Guled immediately volunteered, and therefore they become the participants in the exploratory group interview.

The exploratory group interview can be described as formal since it was carefully pre-scheduled and planned rather than a spontaneous talk (Copland \& Creese, 2015, p. 30). The interview took place during school time in a separate room; it lasted 26 minutes and was videotaped. The interview material furthermore involves 19 photos of apps and functionalities, taken by me during the interview. Roshina, Zohal, Homa and Guled each brought a device containing their quranic app to the interview - Guled and Homa brought their smartphones, 
while Roshina and Zohal opted for their tablets, made available to them by the school. During the interview, they eagerly showed and demonstrated the apps and their functionalities to each other and to me, and the devices provided a concrete and tactile point of departure for a highly interactive and investigative conversation.

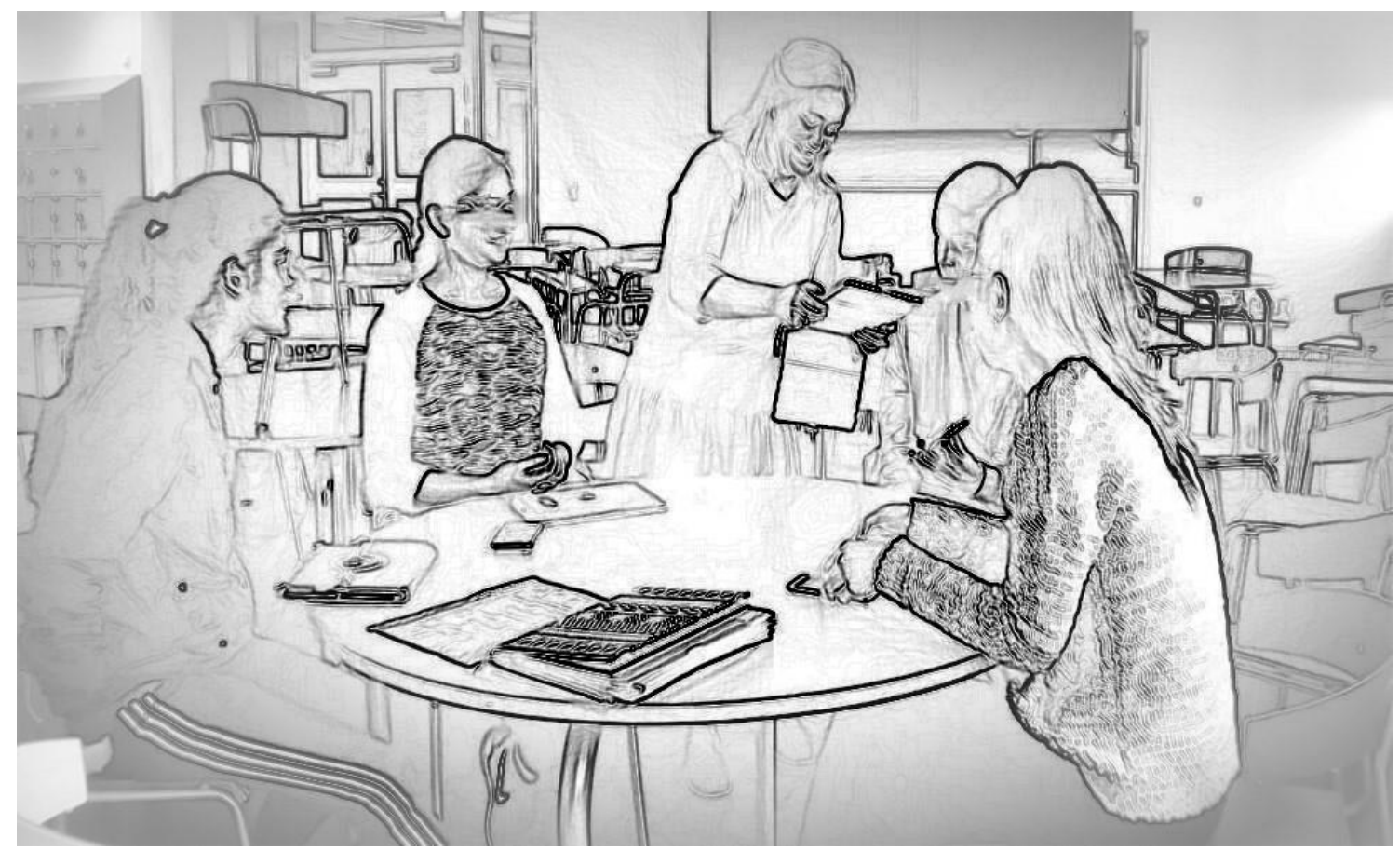

Figure 2. The interview situation. From left to right: Zohal and Roshina (sitting), me (standing) taking a photo of Guled's smartphone, Guled and Homa (sitting).

Whereas from a methodological point of view, the interview can be categorised as formal, the actual dialogue was characterised by an informal and relaxed atmosphere, facilitated by the mutual trust between the pupils and myself built up through the previous eight years of fieldwork. While we had never previously discussed quranic apps specifically, the youth were all familiar with me, with the group interview situation and with talking to me about language, literacy and various aspects of school and youth life.

During the interview, we together explored and manipulated different quranic apps and discussed the young people's criteria and priorities, their practices and strategies for use and their attitudes and understandings. The interview followed a thematically organised interview guide (see Appendix 1). The interview was introduced by demonstration of the young people's apps and their functionalities and then progressed to reflection on selection and quality criteria, practices and preferences and reading strategies. I then invited reflections on a specific quranic app, Den Klare Koran, a newly released app containing the first Danish-medium reading of the entire Quran. Finally, the interview moved from the here-and-now personal sphere to a more abstract and speculative sphere when I invited the young people to formulate tips and tricks to other young users of quranic apps and to envisage the quranic app of their dreams.

While the exploratory group interview yielded important insights into the four young people's quranic app practices, it also has obvious and serious limitations. An important limitation pertains to the nature of the knowledge produced in interviews. An interview on quranic app practices uncovers self-reported 
practices, not enacted practices, and it would have been fruitful to combine the interview data with observations of actual and spontaneous use of quranic apps. Another serious limitation concerns the descriptive and explanatory power of an interview with four young people. Roshina, Zohal, Homa and Guled's practices with quranic apps varied greatly, and other young people may have yet other experiences, preferences, strategies and understandings. Furthermore, the analysis is limited to the four young people's own perspectives. It would undoubtedly have yielded interesting insights to compare Roshina, Zohal, Homa and Guled's perspectives on quranic apps with those of their parents, religious authorities in the Muslim community, literacy teachers or peers.

The analysis performed in this article relying on the exploratory group interview is therefore by no means either representative or conclusive; it is truly exploratory and should be considered a window into a largely unknown language and literacy universe and as a possible starting point for further investigation.

\section{Analysis: Zohal, Roshina, Guled and Homa's quranic app practices}

\subsection{Analytical lens}

The exploratory group interview has been fully transcribed in Danish, relying on both the video recording of the interview and the accompanying photos. The subsequent analysis involved shuttling back and forth between the written transcript and repeated listenings and watchings (see Daugaard, 2015, pp. 90-93 for a more detailed description of the affordances of multimodal analysis). The initial analysis was guided by the themes arising from the interview questions and underlying research questions, but was also open to new emergent perspectives. While the first rough analysis was conducted in Danish, key excerpts were later translated into English as the analysis intensified.

Rosowsky's research on faith literacies has provided important inspiration for the analysis. However, as mentioned earlier, digital quranic practices are largely missing in Rosowsky's many-facetted descriptions of quranic literacy practices. Notable exceptions are sporadic mentions of internet-based resources for religious poems (naat) and songs (nasheed) (Rosowsky, 2010, p. 172) and of bluetooth exchanges of naat resources on smartphone (Rosowsky, 2012, p. 630). The analysis of quranic app practices among multilingual Danish Muslims in this article is thus on the one hand heavily inspired by and relying on Rosowsky's work, but at the same time attempts to elaborate and extend its scope by bringing Rosowsky's analytical framework to bear on a new, digital kind of quranic literacy practice, namely quranic app practices.

The following analysis of Zohal, Roshina, Guled and Homa's quranic app practices falls in four parts. I first describe the four quranic apps used by the young people and then describe their ways of using their quranic apps. Subsequently, I focus on the young people's ways of engaging with the sacred text of the Quran and finally describe how they also use their religious apps for other purposes than engagement with the Quran.

\subsection{Four young people - four quranic apps}

Zohal, Roshina, Guled and Homa use four different quranic apps: 
Table 3. The four quranic apps.

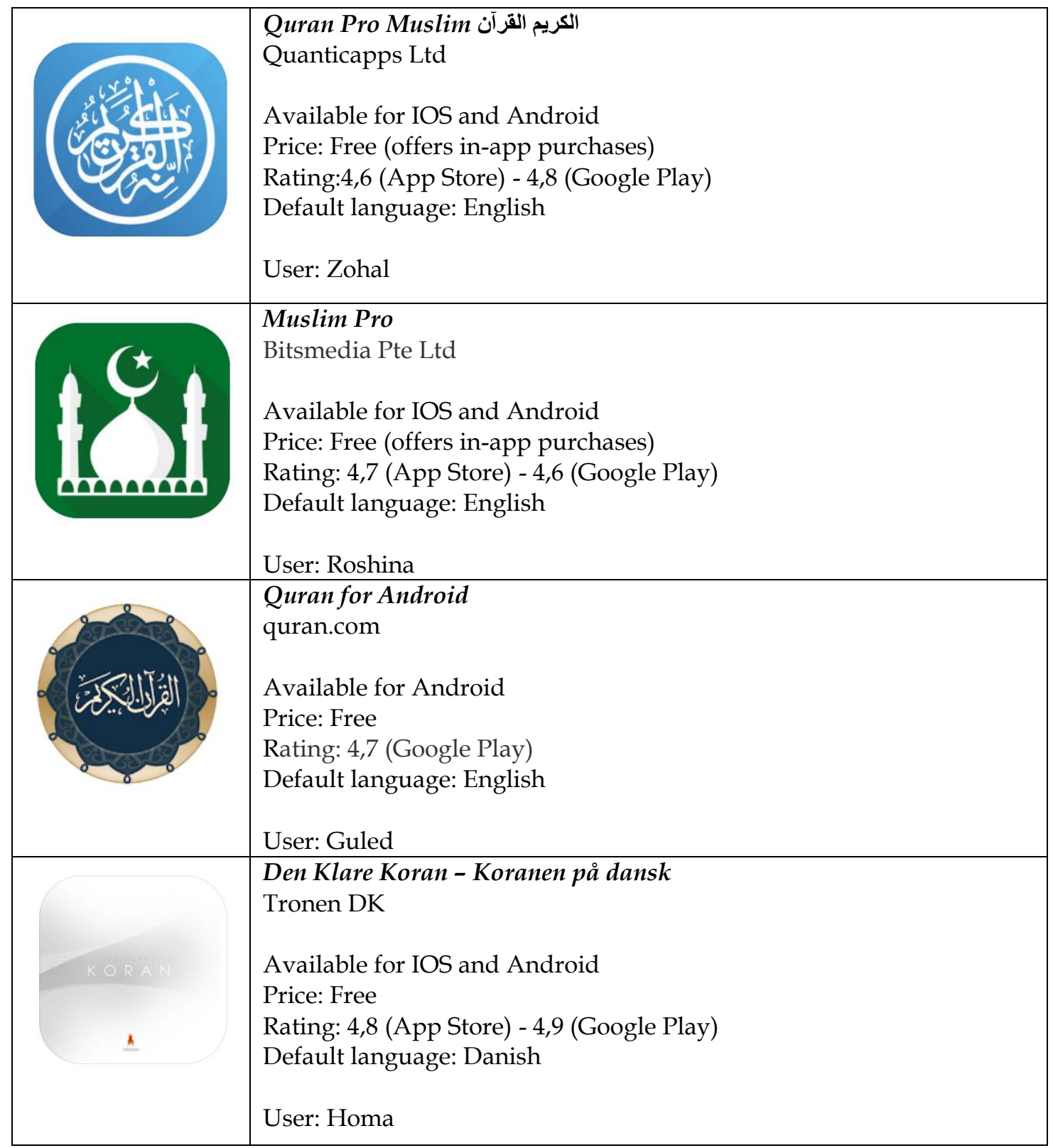

Roshina uses the app Muslim Pro. Muslim Pro is advertised as "the most popular Muslim app in the world" and is according to the developer "recognized by more than 40 million Muslims around the world". However, the app was not recommended to Roshina; she selected it herself after careful investigation of several apps:

I took the one that looked best. Well, I first downloaded all the apps where you can read the Quran and then checked which one was best and picked that one (Roshina)

Roshina further explains that user-friendliness weighed heavily in her selection: "It has to be easy". Functionality is also stressed by Zohal, who uses another app, Quran Pro Muslim. She has relied on a social strategi for selection: "My sister recommended it to me". Zohal especially values the multi-functionality and the range of choice in her app: 
For me, it was more like what I get to choose from. Have the Quran read aloud for instance. There were several things I could use, for instance prayer times. Or Quran reading by different people (Zohal)

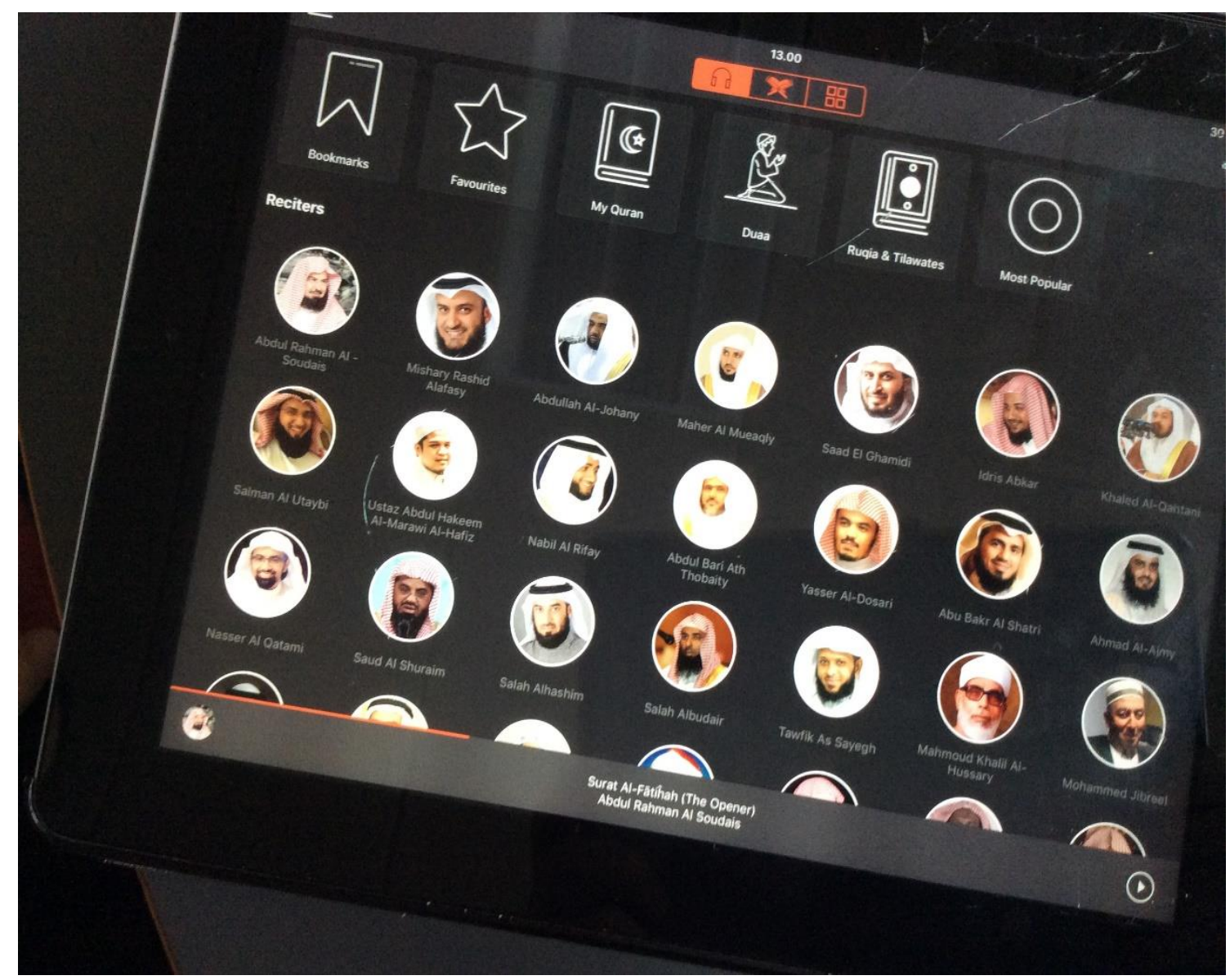

Figure 3. The selection of reciters in Zohal's app Quran Pro Muslim.

Guled's app is called Quran for Android. He is the only Android user of the four and has had a narrower selection of quranic apps to choose from. Whereas the girls can all access their quranic apps on both the iPad provided by their school and their personal iPhones, Guled has only got access to his quranic app on his smartphone. In contrast to Roshina's careful investigation of apps and Zohal's social strategy, he seems to have relied on coincidence: "I took the first one that popped up", he says.

Finally, Homa uses the app Den Klare Koran [Danish for The Clear Quran]. While the others use apps with English language settings, Homa's app has Danish default language settings which was a decisive factor in her selection of the app. Like Zohal, she has heard of the app through social networks:

There was a post on facebook saying that some young Muslims, some Danish Muslims, had made this new app. And then it was also in Danish. And it costs money normally, but it was free for 24 hours. And then I downloaded it! (Homa)

Zohal, Homa, Guled and Roshina have come across their four quranic apps in different ways including advice from siblings or virtual social networks, independent investigation and more or less chance selection. They highlight 
different qualities in their quranic appss: user-friendliness, range of functionalities, affordability and linguistic accessability. As we will see in the next section, these priorities are aligned with their different ways of using their quranic apps.

It is noteworthy that none of the young people make reference to parental or adult influence on their choice of apps. In her study of the use of game-based language and literacy technology and apps in UK-based multilingual families, Little (2019) points to parental attitudes to technology as a salient factor in children's access to and use of technology in the home environment. When it comes to quranic apps, it seems reasonable to assume that parental attitudes may likewise exert significant influence - not least in the light of the moral issues surrounding digitization of the Quran described in Islamic studies. In the questionnaire survey conducted by Khan and Alginahi, a respondent specifically frames his scepticism towards recitation based on quranic apps as a parental concern for future generations (Khan \& Alginahi, 2013, p. 160):

I believe that reciting Quran should be limited to a Mushaf since the Mushaf demands special consideration and care. Our children will grow up not knowing those qualities and considerations of dealing with a Mushaf if we keep looking at screens when reciting Quran, which is going to be a major shortage in their education and respect to Islam and Allah (God).

Zohal, Homa, Guled and Roshina, however, do not mention either parents or other significant adults, including religious authorities, when they describe their choice of quranic apps. Due to the limitations of the exploratory group interviews, it remains unclear whether the parents are knowing of the young people's use of quranic apps and if so, how they perceive the quranic apps. In the following, we move closer to the young people's self-reported ways of using their quranic apps.

\subsection{Quranic app practices: Different ways with apps}

Zohal, Homa, Guled and Roshina describe different ways of using their quranic apps. Guled tells of a relatively structured practice. He goes to quranic school with his younger brother in the weekend and uses the quranic app to practice for quranic school, either to help his brother or - primarily - to rehearse his own recitation skills:

I practice to be able to do it by heart. So I listen first and then pause and then try myself (Guled)

Guled here refers to a recitation function in his app which allows him to mark a small text fragment in Classical Arabic (marked in green), have it read aloud and then attempt to reproduce the recitation himself until the recitation is to his satisfaction: 


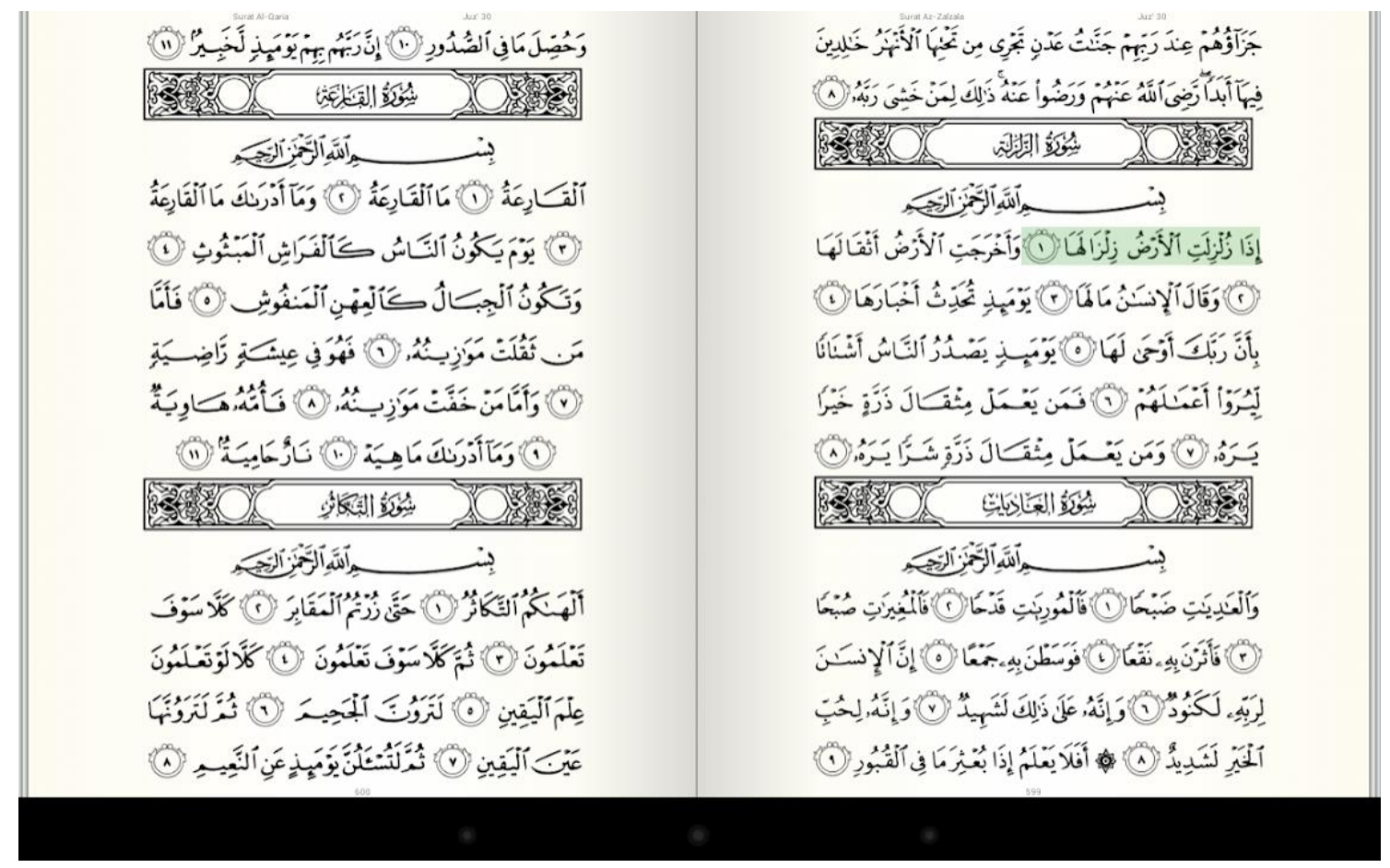

Figure 4. Recitation function in Quran for Android.

(https:/ / play.google.com/store/apps/details?id=com.quran.labs.androidquran\&hl=da)

Rosowsky describes recitation as "quintessential religious classical practice" and stresses that private or public recitation of verses from the Quran is a primary outcome of the acquisition of liturgical literacy (Rosowsky, 2012, p. 623). Since accurate recitation carries high religious and moral value and prestige, the key skills in recitation are accuracy of pronunciation and appropriate tone and rhythm - exactly what Guled's app allows him to practice. While Guled explains that he either rehearses on his own or with his younger brother, the recitation itself is typically a public phenomenon performed before an audience, and recitation as a quranic literacy practice thus has highly performative qualities:

Performativity plays an important role in any analysis of the religious classical and its associated sociocultural practices. The religious classical, one could say, is a language variety that is intimately bound up with performance, much more so than more regular communicative practices for its learning and acquisition are predicated on performance as its raison d'être. The recitation and memorisation, prayer and ritual, of the religious classical are performances through, by and with which religious identity is enacted and embodied. (Rosowsky, 2012, p. 617)

The performative elements of quranic recitation are oriented towards correctness, accuracy and fluency rather than sensitivity to meaning. The accompanying interjections from the audience which are part of traditional recitation in quranic schools or mosques thus constitute "a ritualised response not related to meaning but rather to crests and crescendos in the recitation" (Rosowsky, 2012, p. 632). Guled's quranic app constitutes an important part of his efforts to achieve correct recitation, and this is facilitated by the app's recitation function. Whereas rehearsal of recitation based on a book version of the Quran would require advanced decoding skills and respectance of Islamic rules for handling of the mushaf, the app's recitation function provides easy and repeated access to both 
audio and written versions of the sacred text. In contrast to the respondents in Khan and Alginahi's questionnaire, neither Guled nor the others mention any reservations about using an app for recitation purposes during the interview.

While recitation is at the heart of Guled's seemingly structured and goaloriented use of his quranic app, the three girls tell of more loose and pleasureoriented practices; they rather use their quranic apps on their own and when they feel like it or need it. Roshina says that she has not got a fixed schedule, but uses the app a few times a week, typically by picking a sura and trying to read it in Arabic. Zohal, who presents herself as a less fluent reader of Classical Arabic than Roshina, says that she listens more than she reads:

I don't do it insanely often or on a daily basis. It's just when I kind of feel like it. Like aaah... when I feel like I want to. If I feel like listening to it, because I think it's really beautiful to listen to, then I just turn it on (Zohal)

Zohal here describes the soothing effect of the sound of recitation of the religious classical. As mentioned earlier, Holes describes how the sound of Classical Arabic, heard in prayers or at the mosque, leaves an "indelible impression" on many Muslim children (Holes, 2004, p. 5); Zohal here describes how she uses her quranic app to recreate this impression - whenever and wherever she feels like it. It is therefore natural for Zohal to choose a quranic app like Quran Pro Muslim which is advertised as offering "a concentrate of the best Quran reciters in the world", features a "state of the art audio player" allowing to play audio in the background and contains repeat, shuffle and timer functions:
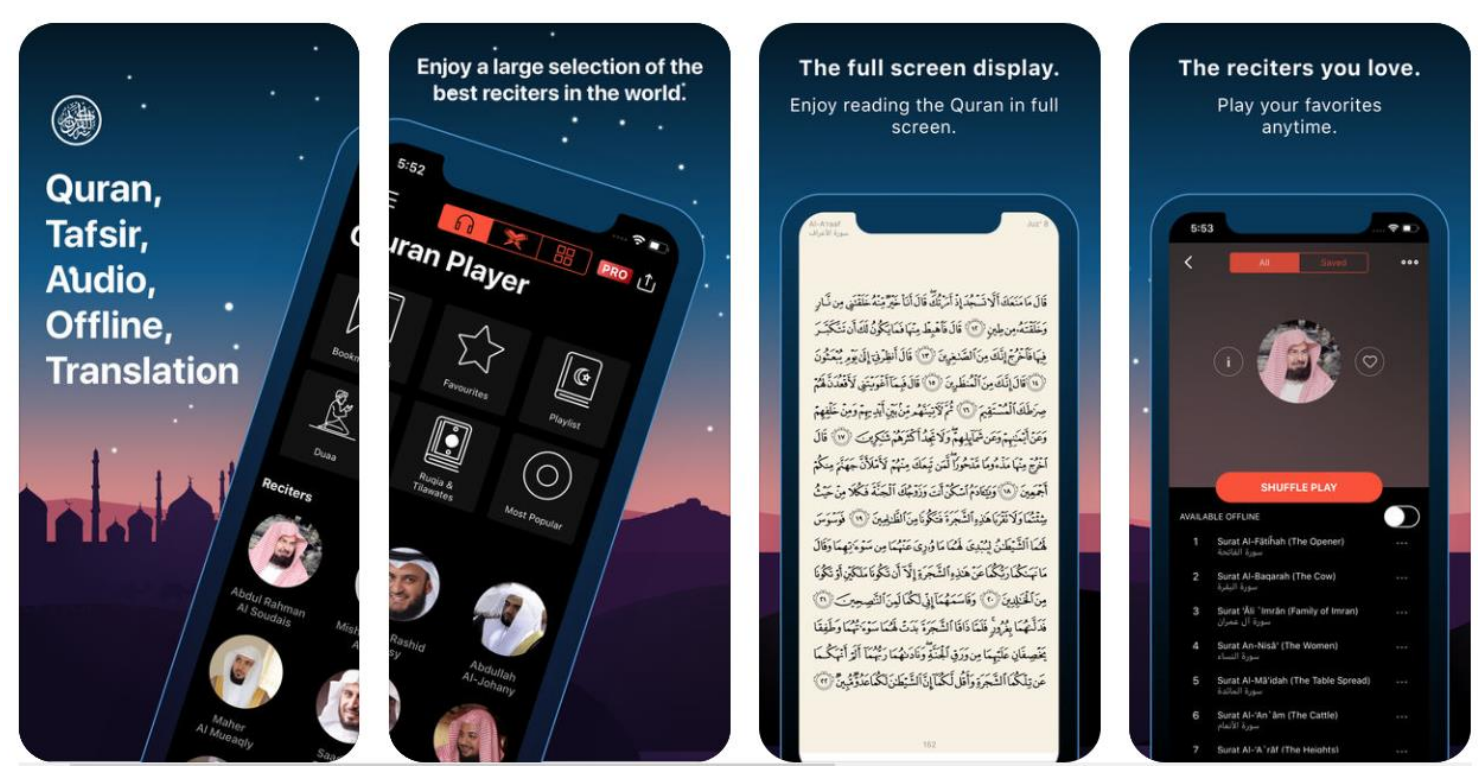

Figure 5. Advertisement for Quran Pro Muslim.

(https://itunes.apple.com/gb/app/quran-pro-muslim)

Like it was the case with Guled's use of his app to rehearse recitations skills, Zohal's use of her quranic app to listen to authoritative and artful recitation highlights the performative nature of recitation. While Guled's app use places him in a performing role as an emergent reciter, Zohal in her quranic app practice takes up the position of audience enjoying established reciters' skillful recitation. 
Guled and Zohal's examples illustrate how the young people's selection and quality criteria for their quranic apps are consistent with their ways of using the apps. Guled prioritises his own productive recitation skills and therefore uses an app with excellent recitation functionalities; to Zohal, the soothing effect of listening to famous reciters is the main objective, and she therefore uses an app offering great playback facilities and a large selection of reciters. At the same time, the young people's uses of their quranic apps are shaped by their confidentiality with and competences in the religious classical. Roshina, who is a fluent reader of Classical Arabic, is able to use her app for independent reading, whereas Guled interacts with the quranic text both receptively and especially productively. Zohal - who despite acting as an assistant teacher in the quranic school in the first years of schooling now describes herself as much less experienced and skilled when it comes to reading Arabic than Roshina - has found another way of engaging with the religious classical, namely through sustained listening. To Homa, understanding the quranic text is primordial, and this had led her to choose a Danish-medium quranic app to which I turn in the next section.

\subsection{Homa's choice: What counts as reading the Quran?}

Homa is the only of the four who has chosen a Danish language quranic app, Den Klare Koran. Den Klare Koran was released in 2015 and was the first quranic app ever to feature a full translation and reading of the entire Quran in a Scandinavian language. The app contains the quranic text in Danish and Arabic and a reading of the Quran in Danish by Isam Bachiri, a well-known young Danish-Moroccan singer who is himself a practicing Muslim.

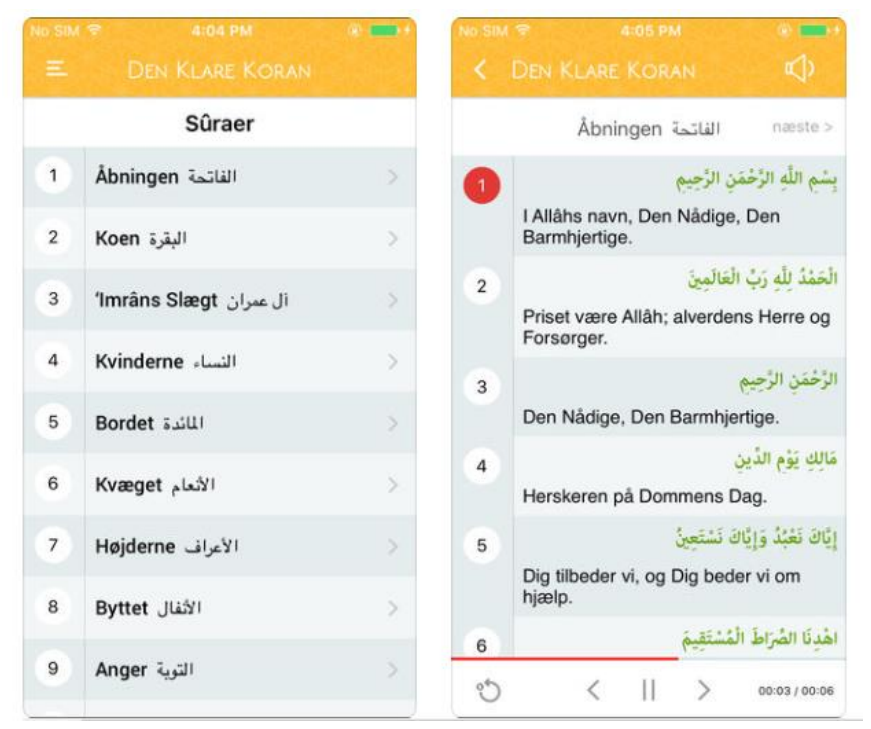

Figure 6. Den Klare Koran.

(https://itunes.apple.com/dk/app/den-klare-koran-koranen-p\%C3\%A5-dansk-teksttale/id1100115085?1=da\&mt=8)

As we have already seen, Homa learned about the new Danish quranic app on facebook. When the young people first present their quranic apps to each other, Homa eagerly exclaims: "Mine is written in Danish!". Guled immediately lifts his eyebrows and asks her if he can see it. He quickly examines Homa's app on her smartphone, then hands it back to her and immediately starts downloading Den 
Klare Koran on his own smartphone. None of the others seems to know the Danish app and like Guled react with interest and curiosity. The ground-breaking Danish-medium version of the Quran is exactly what attracted Homa to her app. She explains:

So if I'm sitting there reading the Quran with my dad, then I don't understand. He just reads. But yeah, if I then read it from this app, then I understand the meaning of it too. That's why you say that in the Quran, you will find the answer to everything. In Islam. But if you don't understand it, what are you supposed to find the answer to then? So it's really better with an app where you can understand the answers if you have a question. And then read the Quran to find answers to questions (Homa)

To Homa, the Danish version of the quranic text not only allows her to read independently: "I mostly read myself because it's written in Danish"; it also allows her to understand the quranic text. This, she claims, is not the case when she reads or listens to the Classical Arabic version of the text:

But I don't understand it. You know, I don't understand the meaning of it. And that's why it's good to have it in Danish too, because then I'm able to understand it (Homa)

The question of language choice for engagement with the Quran is controversial. Homa's insistence on reading the Quran in Danish presents a challenge to the traditional isomorphic relation between the sacred text and its Classical Arabic form. In his investigation of script choices among young multilingual Muslims, Rosowsky found highly contrasting views among the teachers of quranic literacy in mosques and quranic schools. In one mosque, the teacher vividly encouraged the use of learning materials containing transliteration of Classical Arabic using the Roman script; his primary concern was to provide "meaningful hooks" for learning (Rosowsky, 2010, p. 170). In another mosque in the same city, however, the teacher with a similar conviction claimed: "We are totally against it because we fell that we are missing the essence of the Arabic" (Rosowsky, 2010, p. 171). Homa clearly sides with the first view and advances a religious argument for her choice: If a main objective of reading the Quran as a Muslim is to be able to find answers to important questions in the sacred text, then the meaning of the text has to be accessible, and therefore you must read in a language you are able to make sense of.

The question of language choice is thus intricately related to another question, namely what it means to 'read the Quran'. Like the rest of their class, Zohal, Roshina, Guled and Homa have through primary and lower secondary school been socialized into an understanding of reading as a complex process involving both decoding and comprehension and have through lower secondary school been strongly encouraged to develop strategies privileging reading comprehension and meaning. Rosowsky (2013, p. 76) refers to this as a "Rolls-Royce version of reading" in which accurate decoding is accompanied by attention to meaning, and Homa seems to bring this understanding of reading to her engagement with the religious classical.

Guled, on the other hand, has another understanding of what counts as reading the Quran. As we have seen, his engagement with the religious classical is guided by his objective of achieving flawless and beautiful recitation, and this objective can be realized independently of understanding of the text. Rosowsky finds a similar understanding of reading as decoding across the Muslim, Sikh and Jewish faith complementary schools and points out that "understanding of successful reading in all three settings encompasses reading as fluent and accurate decoding, 
which it esteems as a meritorious act of devotion" (Rosowsky, 2013, p. 75). He stresses that the Rolls Royce version of reading found in mainstream schooling is not the default mode of reading in all contexts; in faith settings, devotional reading has other purposes, and therefore decoding is considered both sufficient and most apt. It is important to notice that the two understandings of reading are neither mutually exclusive nor necessarily conflicting in everyday life of the young religious heritage learners of Arabic. Throughout mainstream schooling, Guled has been considered a skilled reader - in the Rolls Royce school-based and meaning-oriented understanding of reading - and nothing suggests that he has limited reading skills or that his reading in school is biased towards decoding. As Rosowsky (2013, p. 76) aptly points out, devotional reading of the religious classical may focus little on meaning, but that does not mean that the reading practices are meaningless. On the contrary, learning to decode the religious classical has high symbolic value and constitutes an important identity-affirming process.

Homa and Guled bring two very different understandings of what it means to read the Quran to bear in the exploratory group interview. Both understandings appear coherent, meaningful and legitimate, and both understandings are aligned with their individual ways of choosing and using their quranic apps. Even if Guled himself uses a very different quranic app, he acknowledges the religious potential of Homa's app:

I think it's great that they have made this new quranic app. Because then it's easier. And that will help more people understand the Quran (Guled)

However, while they all four contend that it is good to have a Danish version of the quranic text - in text as well as in recorded audio format - they regret that Den Klare Koran only contains Arabic text, but no Arabic language recording and therefore no possibility of listening to the Quran in Classical Arabic. Even Homa, who has actively and insistently advocated the potentials of the Danish text version of the Quran for independent reading purposes, refers to Classical Arabic as "the right way" of reading the Quran aloud. This shows how the language ideological saturation, which has surrounded the Quran and Classical Arabic for more than 14 centuries, vividly resonates in contemporary quranic app practices among multilingual Muslim youth in Denmark.

\subsection{Quranic apps: Beyond sacred text}

Engagement with the sacred text of the Quran - whether in reading, listening or reciting and in Classical Arabic or Danish - is the primary reason for the four young people to have and use a quranic app. But as suggested by Campbell and colleagues' typology of functions of religious apps, the quranic apps serve a range of other purposes as well. Especially Roshina and Zohal highlight multifunctionality as a central quality in a quranic app. While Zohal's app has a remarkable range of reciters, Roshina's app Muslim Pro has an impressive range of functionalities: 


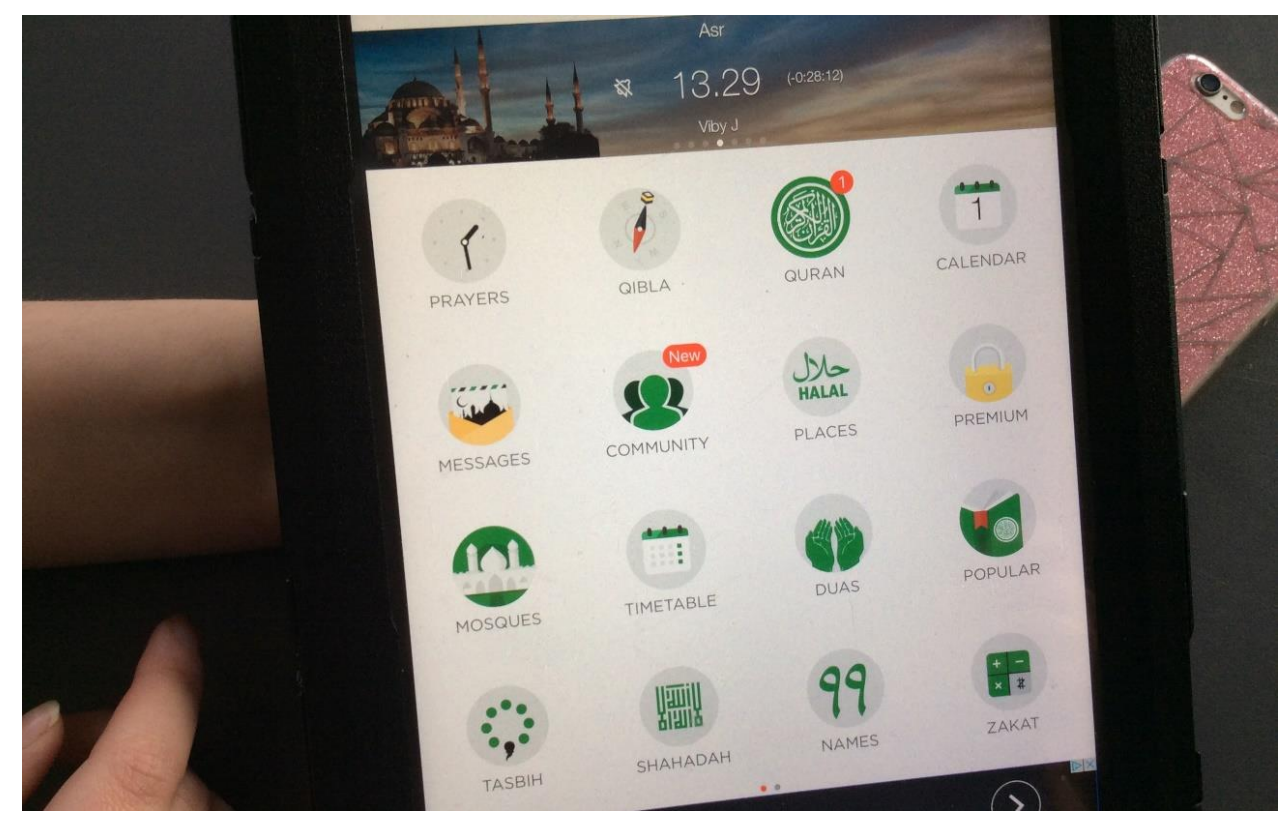

Figure 7. Overview of functionalities in Muslim Pro.

The quranic text is just one among many functionalities in Muslim Pro. The app also contains an Islamic calendar, prayer times (salah), examples of prayers (dua), the Islamic confession of faith (shahadah), the 99 names of Allah, a list of the nearest mosques and many others. In a recent study of the perceived affordances of Muslim Pro among young Muslims in Malaysia, Rosli and Rahim aptly describes Muslim Pro as an "all in one application" (Rosli \& Rahim, 2016, p. 40). Their survey shows that the young Malayans judged Muslim Pro to be relatively easy to use and at the same time believed that the comprehensive and multi-functional app supported "critical aspects of their Muslim lifestyle" (Rosli \& Rahim, 2016, p. 39) - exactly the two qualities which Roshina values in a quranic app.

During the interview, Roshina demonstrates some of the functionalities. Some appear mainstream to the others - for instance the digital compass which enables the app user to locate the direction of the Kaaba in Mecca (qibla). Other functionalities clearly appear new and exciting to the others. This especially goes for the digital string of prayer beads (misbaha) which Guled and Homa have never seen before and appear fascinated by:

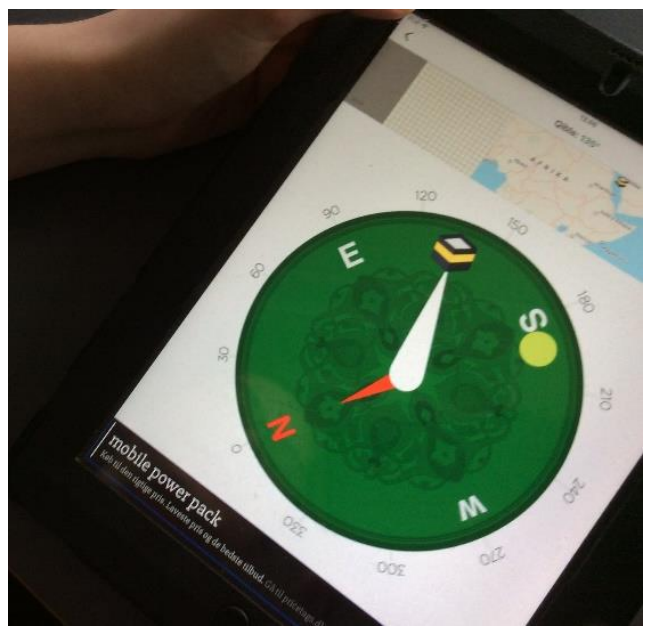

Figure 8. Qibla.

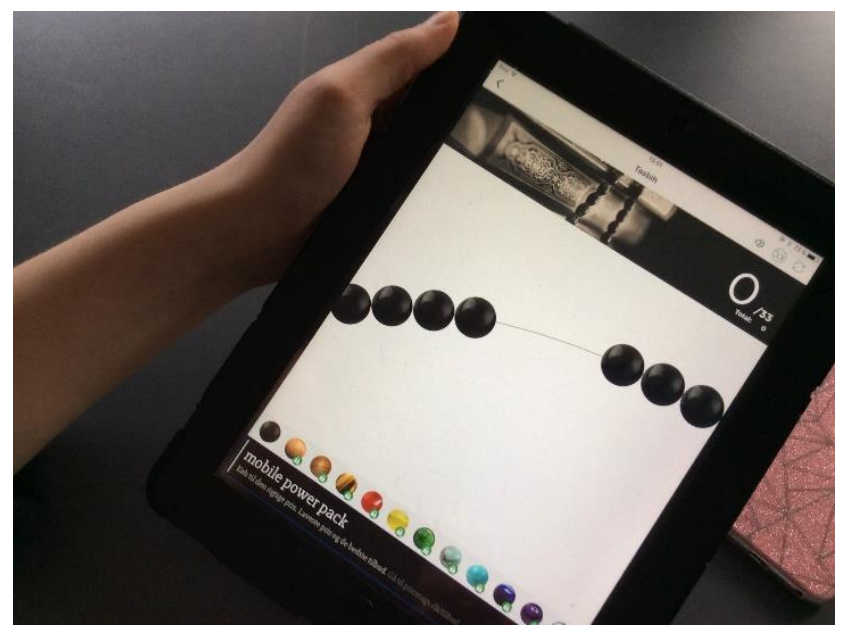

Figure 9. Misbaha. 
All four have another religious app called Halal Check. Amir, Yusop and Kamarulzaman (2016) distinguish between four types of halal-based apps: halal food geo-locators, halal scanners, halal directories and halal recipes. As is clear from Guled's explanation, Halal Check is a halal scanner:

There's an app where you can take photos of those bar codes on food that they use in shops so you can check if it's halal (Guled)

Halal Check is obviously a religious-oriented app, but not a quranic app. In Campbell and colleagues' typology, it belongs to the subcategory of Religious Utilities within the parent category of apps embedded with religious content. The presence of Halal Check in Zohal, Roshina, Guled and Homa's narratives show that even if their religious apps are centered around engagement with the Quran as sacred text, they serve a broader range of functions in the young people's everyday lives. Both the quranic apps and other religious apps help them navigate the word and the world - in a Freirean sense - as young Danish Muslims.

\section{Conclusion and discussion}

In this article, I have shed light on the quranic app practices of four young heritage learners of Arabic: Roshina, Zohal, Guled and Homa. They have different linguistic backgrounds, speak different languages at home and have different levels of Arabic literacy competence, but all consider themselves practicing Muslims and all regularly use quranic apps.

The analysis shows that the quranic apps take up different functions in the young people's everyday lives. Through the quranic apps, they engage with the sacred text of the Quran in different ways, with different objectives and drawing on different languages. The quranic practices primarily unfold privately and individually, but may also involve siblings. The quranic apps are used productively - for reading and reciting - as well as receptively - for listening. All quranic app practices involve engagement with Classical Arabic, but may also productively involve use of Danish and to a lesser extent English as an auxiliary language.

Roshina, who speaks Dari at home and is a fluent reader of Classical Arabic, uses a comprehensive English-Arabic quranic app; primarily for silent and independent reading of the Quran in Arabic, but also to check prayer times and find prayer texts. Somali-speaking Guled also uses an English-Arabic quranic app, but in his case primarily to rehearse his recitation skills in Classical Arabic before quranic school. Zohal's quranic app is also English-Arabic; she primarily uses the app's playback function and enjoys listening to famous reciters of the Quran in Classical Arabic. Like Roshina, Homa's use of her quranic app is oriented towards independent reading. Because understanding of the meaning of the Quran is primordial to her, she has chosen to use a Danish-Arabic quranic app featuring the quranic text in Danish and Arabic and a recording of the entire Quran in Danish.

The analysis thus reveals radically different understandings of that it entails to 'read the Quran'. To Roshina, it is a question of reading the quranic text silently and independently; to Guled, it is about reciting flawlessly; to Homa, it is an intense search for the meaning of the Quranic text; and to Zohal, it is about the 
blissful and soothing sound of Classical Arabic. While there is great variation in the four young people's quranic app practices, it is important to stress that in each case, the young people's choice of app seems consistent with their stated objectives, priorities, preferences and practices, and the different quranic practices thus all appear meaningful, consistent and legitimate.

Across the four young people's ways with quranic apps, it is a remarkable characteristic that using a quranic app is a profoundly emotional enterprise. This is especially salient in Zohal's description of the comfort and bliss that the listening to her favorite reciters brings her, but also Homa's quest for meaning in Danish and Guled's striving for flawless recitation are highly emotionally invested endeavours. In a time where Classical Arabic - iconized by the phrase Allahu Akbar - may in large parts of public discourse readily and uncritically be associated with radical Islamism and imminent terror threat, it is no trivial fact that the sound of Classical Arabic or the sight of quranic writing can also procure peace of mind and a feeling of security.

While the analysis in this article has provided interesting insight into Roshina, Zoha, Guled and Homa's quranic app practices, many questions remain unanswered and open to further investigation due to the severe limitations of the explorative group interview. Among the unexplored issues are the possible meaning of gender and cultural background for quranic app practices. Are there gendered patterns in choice and use of quranic apps? Or are quranic app practices shaped by cultural background or affiliation to ethno-linguistic communities? Likewise the relations between the young quranic app users and significant adults call for further exploration: To what extent are parents' and religious a uthorities knowing of the young peoples's use of quranic apps? Are they sceptical or approving - and why? Are there intergenerational tensions, or may quranic apps function as a bridge across generations? Finally, a series of questions arise when it comes to the relation between quranic app practices and mainstream schooling: To what extent do mainstream school literacy teachers know about and acknowledge young people's engagement with the religious classical outside of school? May such insights be of value to literacy teaching in school?

Finally, the use of quranic apps among young multilingual Muslims in diasporic settings raise sociolinguistic questions of language maintenance and shift religious communities. Based on his research in UK-based Muslim communities, Rosowsky (2010) poses the question whether a process of gradual language shift is under way: Is there a move away from the traditional privileging of Classical Arabic as sole medium of religious practice in favour of using English or heritage languages such as Panjabi for religious practice among young Muslims?

To determine whether this could likewise be the case among young Danish Muslims obviously requires further research, but young heritage learners of Arabic like Homa may turn out to be first movers in such a movement. In the language portraits of Homa's classmates, there is some evidence to suggest that this may be the case. Aisha, who is Homa's friend and like Homa has an Afghan background, did not volunteer for the exploratory interview on quranic app practices. But after the interview, the two girls - as well as several classmates - in informal conversations discussed quranic apps and issues arising from the exploratory group interview, and these conversations seem to have left their marks on several language portraits produced in Year 9. Aisha herself accords Arabic a privileged position in her language portrait. In the visual language 
portrait, she portrays Arabic as a large scarf thrown around her neck to keep her warm, and in the written essay she explains:

The scarf around my neck illustrates the Arabic alphabet. I included it because it is a large part of my life. I learned to read it though the Quran, however I don't understand it, and therefore I read the Quran's translation to Danish so I understand what I read (Aisha)

In this statement, Aisha seems to revoice the convictions of her friend Homa possibly intermingled with authoritative mainstream school discourses on the importance of meaning and understanding in reading. Her statement - like Homa's quranic app practice - indicate that the Danish language may be gaining terrain in religious practice. In this regard, it is noteworthy that Somali, Pashto and Dari-language quranic apps or translations do exist, but that none of the young people mention these or seem aware of their existence. To the extent that other languages than Classical Arabic are given a role in quranic app practices, it is Danish - the 'second language' of the young people - and not their 'heritage' or 'home' languages Somali, Dari and Pashto.

Further research is needed to explore the future development in young Muslims' choice of language for religious practice in Denmark as well as in other diasporic settings. Regardless of the limitations of exploratory group interview which this article is based on, the findings call for further exploration of young people's quranic app practices - in Denmark and elsewhere. Further exploration of quranic app practices among young multilingual Muslims can not only shed new light on the role of Arabic language and literacy in transnational and diasporic communities, it may also challenge received understandings of what counts as reading and as literacy and - most importantly - can provide new insights into what it means to be a young Muslim in a globalized and digitized world.

\section{References}

Aarset, M. F. (2016). Transnational practices and local lives: Quran courses via Skype in Norwegian-Pakistani families. Identities, 23(4), 438-453.

Alwi, E., Anas, N., Ibrahim, M., Dahan, A., \& Yaacob, Z. (2014). Digital Quran applications on smart phones and tablets: A study of the foundation programme students. Asian Social Science, 10(15), 212-216.

Amir, H., Yusop, F. D., \& Kamarulzaman, Y. (2016). Combating Halal misconceptions among Muslims and Non-Muslims: The potential use of mobile learning application. Paper presented at 3rd International Halal Conference, November 2016, Shah Alam: Selangor.

Bellar, W. (2012). Pocket full of Jesus: Evangelical Christians' use of religion iPhone applications. (Unpublished Master's thesis). Syracuse University, New York.

Busch, B. (2018). The language portrait in multilingualism research: Theoretical and methodological considerations. Working Papers in Urban Language \& Literacies, 236, 1-13.

Campbell, H. (Ed.). (2013). Digital religion: Understanding religious practices in new media Worlds. London: Routledge.

Campbell, H., Altenhofen, B., Bellar, W., \& Cho, K. J. (2014). There's a religious app for that! A framework for studying religious mobile applications. Mobile Media $\mathcal{E}$ Communication, 2(2), 154-172.

Copland, F., \& Creese, A. (2015). Linguistic Ethnography: Collecting, analysing and presenting data. London: Sage.

Daugaard, L. M. (2015). Sproglig praksis i og omkring modersmålsundervisning. En lingvistisk etnografisk undersøgelse [Linguistic practices in and around mother tongue teaching. A 
linguistic ethnographic study of language teaching across the curriculum] (Unpublished doctoral dissertation). Aarhus: Aarhus Universitet.

Daugaard, L. M. (2017). Ind i teksten. Læsestrategisk arbejde i det flersprogede klasserum [Into the text: Working with reading strategies in the multilingual classroom]. In H. P. Laursen (Ed.), Tegn på sprog - tosprogede elever lærer at læse og skrive: Statusrapport 10 [Signs of Language: Status report 10] (pp. 50-62). Retrieved from https://ucc.dk/sites/default/files/statusrapport_2017_final.pdf

Daugaard, L. M., Jensen, N. H., \& Kristensen, K. S. (2018). Hvem er'de nyankomne elever'? Sprogportrætter som redskab i basisundervisningen i dansk som andetsprog [Who are 'the newly arrived pupils'? The language portrait as method in basic teaching of Danish as a second language]. In L.M. Daugaard, N. H. Jensen, \& K. S. Kristensen (Eds.), Nyankomne elever $i$ skolen. Sprogpxdagogiske og -didaktiske perspektiver på basisundervisning $i$ dansk som andetsprog [Newly arrived pupils in school. Language pedagogical and didactic perspectives on basic teaching of Danish as a second language] (pp. 9-29). Aarhus: KVaN.

Gregory, E., Choudhury, H., Ilankuberan, A., Kwapong, A., \& Woodham, M. (2013). Practice, performance and perfection: Learning sacred texts in four faith communities in London. International Journal of Sociology of Language, 220, 27-48.

Haeri, N. (2000). Form and ideology: Arabic sociolinguistics and beyond. Annual Review of Anthropology, 29, 61-87.

Holes, C. (2004). Modern Arabic. Structures, functions, and varieties. Washington: Georgetown University Press.

Holstein, J. A., \& Gubrium, J. F. (1995). The active interview. Thousand Oaks: Sage.

Khan, M., \& Alginahi, Y. (2013). The Holy Quran digitization: Challenges and concerns. Life Science Journal, 10(2), 156-164.

Krumm, H., \& Jenkins, E. (2001). Kinder und ihre Sprachen - lebendige Mehrsprachigkeit: Sprachenportraits gesammelt und kommentiert von Hans-Jürgen Krumm [Children and their languages - lived multilingualism: Language portraits collected and commented by Hans-Jurgen Krumm]. Wien: Eviva.

Laursen, H. P. (2013). Umbrellas and angels standing straight - a social semiotic perspective on multilingual children's literacy. International Journal of Bilingual Education and Bilingualism, 16(6), 690-706.

Laursen, H. P., Daugaard, L. M., Orluf, B., Wulff, L., Ladegaard, U., \& Østergaard, W. (2018a). Literacy og andetsprog $i$ udskolingen. Ni forløb fra Tegn på sprog [Literacy and second language in lower secondary school. Nine examples from Signs of Language]. Retrieved from https://ucc.dk/sites/default/files/literacy_og_andetsprog_i_udskolingen._ni_ forloeb_fra_tegn_paa_sprog_.pdf

Laursen, H. P., Daugaard, L.M., Orluf, B., Wulff, L., Ladegaard, U., \& Østergaard, W. (2018b). Metalanguaging matters: Multilingual children engaging with "the meta". International Journal of Bias, Identities and Diversities in Education, 3(1), 22-39.

Laursen, H. P., \& Mogensen, N. D. (2016). Timespacing competence: multilingual children's linguistic worlds. Social Semiotics, 26(5), 563-581.

Little, S. (2019). 'Is there and app for that?' Exploring games and apps among heritage language families. Journal of Multilingual and Multicultural Development, 40(3), 218-229.

Prasad, G. (2014). Portraits of plurilingualism in a French international school in Toronto: Exploring the role of visual methods to access students' representations of their linguistically diverse identities. The Canadian Journal of Applied Linguistics, 17(1), 51-77.

Rosli, H., \& Rahim, R. (2016). A study of the Malaysian youth perception toward 'Muslim pro' apps through smart phone in Malaysia using technology acceptance model (TAM). Paper presented at ISME Colloquium, June 2016, Melaka: Pengukuhan Budi Dan Jati Diri.

Rosowsky, A. (2008). Heavenly readings: Liturgical literacy in a multilingual context. Clevedon: Multilingual Matters.

Rosowsky, A. (2010). "Writing it in English": script choices among young multilingual Muslims in the UK. Journal of Multilingual and Multicultural Development, 31(2), 63-179.

Rosowsky, A. (2012). Performance and flow: The religious classical in translocal and transnational linguistic repertoires. Journal of Sociolinguistics, 16(5), 613-637. 
Rosowsky, A. (2013). Faith, phonics and identity: Reading in faith complementary schools. Literacy, 47(2), 67-78.

Rosowsky, A. (2015). Faith literacies. In J. Rowsell \& K. Pahl (Eds.), The Routledge handbook of literacy studies (pp. 169-182). London: Routledge.

Street, B. (1984). Literacy in theory and practice. Cambridge: Cambridge University Press.

Street, B. (1995). Social literacies. Critical approaches to literacy in development, ethnography and education. Harlow: Pearson Education.

Street, B. (2001). Literacy events and literacy practices: theory and practice in the New Literacy Studies. In M. Martin-Jones \& K. Jones (Eds.), Multilingual literacies: reading and writing different worlds (pp. 17-30). Amsterdam: John Benjamins,

Street, B., Pishghadam, R., \& Zeinali, S. (2015). Changes and challenges of literacy practices: A case of a village in Iran. International Journal of Society, Culture $\mathcal{E}$ Language, $3(1), 16-27$.

Tanggaard, L., \& Brinkmann, S. (2010). Interviewet: Samtalen som forskningsmetode [The interview: Conversation as research method]. In S. Brinkmann \& L. Tanggaard (Eds.), Kvalitative metoder. En grundbog [Qualitative methods. A basic reader] (pp. 29-53). Frederiksberg: Hans Reitzels Forlag.

Temples, A. L. (2013). Constructing Arabic as heritage: Investment in language, literacy, and identity among young U.S. Learners. (Unpublished doctoral dissertation). Atlanta: Georgia State University.

Torma, R., \& Teusner, P. (2011). iReligion. Studies in World Christianity, 17(2), 137-155.

Vollmer, S. (2017). Exploring the digital literacy practices of Rojan, a newly arrived Syrian refugee. Fokus, 68, 14-18.

Vollmer, S. (2018). Syrian newcomers and their digital literacy practices. Language Issues, 28(2), 66-72.

Wagner, R. (2013). You are what you install: Religious authenticity and identity in mobile apps. In H. Campbell (Ed.), Digital religion: Understanding religious practices in new media worlds (pp. 199-206). London: Routledge. 


\section{Appendices}

Appendix 1. Interview guide for exploratory group interview on quranic app practices.

\begin{tabular}{|l|l|}
\hline Research theme & Interview questions \\
\hline Overview & Which quranic apps do you have? Show us! \\
\hline $\begin{array}{l}\text { Selection and quality } \\
\text { criteria }\end{array}$ & $\begin{array}{l}\text { How did you pick your quranic app? } \\
\text { What's important to you in a quranic app? Recitation? } \\
\text { Language, translation? Offline? Price? Reviews, recommendation? } \\
\text { Have you tried other quranic apps? } \\
\text { What makes a good and a less good quranic app to you? }\end{array}$ \\
\hline Practices and preferences & $\begin{array}{l}\text { How do you use your quranic apps? } \\
\text { When, where, how, with whom? } \\
\text { Where do you also read the Quran - outside the app? }\end{array}$ \\
\hline Reading strategies & $\begin{array}{l}\text { What's reading like in a quranic app? } \\
\text { How about decoding; what do you do to decode? } \\
\text { Or does the app read aloud to you (recitation)? } \\
\text { How about understanding; what do you do to understand? } \\
\text { Is it important? Why, why not? }\end{array}$ \\
\hline Den Klare Koran & $\begin{array}{l}\text { Do you know the new Danish-Arabic quranic app, Den Klare Koran? } \\
\text { What do you think? Why? }\end{array}$ \\
\hline Tips, tricks and dreams & $\begin{array}{l}\text { Have you got good advice to others about reading the Quran via app? } \\
\text { What would your dream app look like? }\end{array}$ \\
\hline
\end{tabular}

Received October 23, 2018

Revision received June 27, 2019

Accepted November 25, 2019 